\title{
Scott Walden (ed.), Photography and Philosophy: Essays on the Pencil of Nature, Wiley-Blackwell, 2008, p. 325 [Polish edition: Fotografia i filozofia. Szkice o pędzlu natury, trans. Izabela Zwiech, Cracow: Universitas, 2013, p. 380]
}

DOI: http://dx.doi.org/10.12775/RF.2016.044

Recently, the Universitas publisher has released a Polish translation of a book edited by a British theoretician and practitioner of photography Scott Walden entitled Photography and Philosophy. Essays on the Pencil of Nature. The post-conference collection consists of thirteen interesting articles on the subject of photography and constitutes a part of an extremely rich collection of studies and analyses of issues of broadly defined aesthetics of the visual arts and the philosophy of $\operatorname{art}^{1}$.

A major advantage of this collection, first of all, is the fact that it encompasses texts which present the topic of photography in different, sometimes very distant contexts. For instance, Aaron Meskin and Jonathan Cohen write of photography as evidence material. The concept of the truth and fiction in photography, repeatedly evoked by classicists, reappears ${ }^{2}$ (the article by Scott Walden, Kendall L. Walton, Roger Scruton), whilst the topic regarding the composition and spatial relations

* The project was financed by the National Science Centre for the doctoral scholarship upon the decision no. DEC-2016/20/T/HS1/00470.

1 Amidst all fields of artistic activity, the works of art, studies and articles which are concerned with photography make up the most abundant group. Among the authors who wrote about photography we will find: Susan Sontag, Roland Barthes, Vilem Fluser, Siegfried Kracauer, Bernd Stiegler or Jean Baudrillard.

2 The problem of truth in photography, on the other hand, was addressed, for instance, by André Rouillé. In the course of his deliberations the researcher concludes that only a photograph with specified features may convey the truth. The determinants of truth in photography are focus, flash, expression and transparency. Hence, the carrier of truth is documentary photography. Rouillé thereby rejects artistic photographs characterised by a blur and a significant interference of an artist-photographer. Cf. A. Rouillé, La Photographie: Entre document et art contemporain. Paris: Gallimard 2005. 
in photography is handled by Patrick Maynard. Dominic Lopes, on the other hand, presents his reflections on the problem of an appropriate assessment of a work of art. The authors of the said collection also address the issue of perception and the problem connected with the mechanicity of photographers' work (Kendall L. Walton). However, the multiplicity of depictions and the presentation of interesting and diversified ways of interpretation does not break the collection up into separate, unrelated parts as the second advantage of the book is that the authors of particular articles engage in a dispute with one another. Often, one article constitutes a polemic or response to the theses proposed in another text. Particular authors involve in a written discussion, refer to the content of the texts included in the collection and seek to persuade other researchers to accept their arguments. Because of this, the collection is characterised by a highly dynamic narration; it is coherent, with the articles complementing one another. An example of a such an exchange of views is Kendall L. Walton's Transparent Pictures: On the Nature of Photographic Realism and the article by Cynthia Freeland Photographs and Icons.

Walton puts forward a very controversial thesis in his article. Namely, he claims that photography is nothing else but the result of a mechanical process whose course cannot be influenced by anyone, not even the photographer. Walton states the following:

Some objections focus on the idea that photographs owe their special status to their "mechanical," "automatic" origins, whereas paintings are "handmade." What is crucial is supposed to be the involvement of a person in the process. Several writers have managed to imply that people don't make photographs.18 In any case the remarkable realism of photographs is considered to derive not from what they look like but from how they come about. On this point I agree ${ }^{3}$.

According to Walton, there is no such thing as the photographer's intention or idea. What contributes to the creation of an image consists solely in the optical-chemical or optical-mechanical process. In the researcher's opinion, mechanicity is the main feature of photography, whereas another one is transparency which consists in the fact that we may look at a photograph in the same way as we see the things that lie on the other side of the window. The said transparent character of a photograph allows establishing a contact with what is in it. Walton gives the example concerning the figure of Beethoven: if we were to discover a photograph of him, we would literally see the great composer. The transparency that enables realism is what paintings are deprived of.

3 S. Walden, Photography and Philosophy: Essays on the Pencil of Nature. WileyBlackwell 2008, p. 33. 
According to the author the feature of transparency confers a particular cognitive value upon photography thanks to which it is particularly useful as evidence material. He writes: "Photographs of a crime are more likely to be admitted as evidence in court than paintings or drawings are $^{\prime \prime 4}$. This issue is addressed by Aaron Meskin and Jonathan Cohen. Interestingly, however, in their article Photographs as Evidence they criticise Walton's transparency thesis. According to the authors, during the perception of the world, the man obtains information about the visual properties of things (V-information) and information about spatial locations of those things in relation to the body of the viewer (E-information). Photography is a rich source of the so-called V-information, whereas it will never provide E-information. A complete seeing through a photograph, and thus, the complete realism will therefore never be possible.

However, in my opinion, while writing of realism and authenticity of photography Walton does not address a very important issue regarding the interpretation of photography. Roland Barthes $\mathrm{n}$ his dissertation $\mathrm{La}$ Chambre claire, Note sur la photographie relates to early considerations of Jean Paul Sartre and concludes that photography disguises two aspects: the real world, i.e. the photograph we look at and the imaginary world, i.e. our interpretation of that photograph ${ }^{5}$, whilst François Soulages in his book Esthétique de la photographie notes that without a context a photograph means nothing. We may provide a photograph with any context, hence also with any interpretation. However, the choice of a particular context is synonymous with the loss of all the other ones. In his deliberations, Soulages reaches the conclusion that photography boils down to the aesthetics of choice, i.e. the provision of a suitable context, interpretation, and aesthetics of possibilities, i.e. the possibility to introduce modifications in a given photograph, perform prints, magnify it, cut out

4 Ibidem, p. 14.

5 In his early phenomenological texts Jean-Paul Sartre mainly dealt with the concept of reflective and non-reflective consciousness and the possible acts of nonreflective consciousness. Sartre distinguished three forms of non-reflective consciousness: perceptual, emotional and imaginary. To explain it very briefly: perceptual consciousness registers all the external impressions in our perception, thus it is of a passive character. In perceptual consciousness things appear fragmentarily, establish mutual relations and must be subject to principles of time and space; emotional consciousness is understood (after Heidegger and Husserl) as a human way of being in the world; imaginary consciousness is simply the opposite of perceptual consciousness. If an act of perception assumes the existence of certain objects, then the act of imagination will have the opposite effect, i.e. be based on the assumption that objects do not exist. Imaginary consciousness constitutes an object but does not perceive it as it is not given in the "form" of perceptual consciousness. An object created as an image is absent, non-existent. Therefore, the act of imagining depicts the reality as nothingness. Cf. J.-P. Sartre, L'Imaginaire: Psychologie phénoménologique de l'imagination. Paris: Gallimard, p. 1940. 
selected elements from the photograph, etc. ${ }^{6}$ A similar view is expressed by Susan Sontag who in the essay collection On Photography states that a photograph means nothing without a context and, moreover, it has no effect on the viewer. A photograph acquires its meaning only when we interpret it. ${ }^{7}$ According to Sontag, we tend to keep only these photographs which mean something to us and which we understand because we know their context. A photograph moves us, has an effect on us only when we inscribe it in a defined context, for instance, political. Only a suitable context, and thereby - interpretation, causes that a photograph we look at becomes to us the carrier of truth and authenticity.

The topic of transparency raised by Walton is considered by Cynthia Freeland, however in the context of religious icons. The researcher claims that icons serve as manifestations, which enables the establishment of a special contact between the icon and the viewer.

The status of the icon as an image or likeness is unique because of (a) its subject matter, (b) the beliefs and attitudes it inspires in viewers, (c) its causal origin, and, finally, (d) its reproducibility. First, the icon is a likeness in the sense not of resembling but of being a manifestation or appearance of its prototype. I call this the icon's «authentic manifestation» aspect. $^{8}$

Freeland wonders whether, due to that fact, photographs also may act as manifestations of people and whether such manifestation is possible thanks to its mechanical character: "Such manifestation has less to do with effecting a realistic likeness than with supplying the viewer with a sense of contact or presence with the represented subject. ${ }^{9}$

Other concepts in whose context photography is discussed are veracity and objectivity. These topics are addressed by the collection's editor Scott Walden in the article Truth in Photography and by Barbara Savedoff in the text entitled Documentary Authority and the Art of Photography. Walden claims that both veracity and objectivity are not the qualities of photography itself. Veracity is connected with the thoughts arising from viewing an image, whereas objectivity is compared to Walton's mechanicity and understood as the said optical-mechanical process of rendering photographs. While writing about veracity and objectivity, Barbara Savedoff introduces the term documentary authority. ${ }^{10}$ In her article, she analyses abstract and surreal photographs, i.e. such that undermine

6 F. Soulages, Esthétique de la photographie: la perte et le reste. Paris: Nathan, 1998.

S. Sontag, On Photography. New York: Anchor Book, 1990.

8 S. Walden, Photography and Philosophy: Essays on the Pencil of Nature. WileyBlackwell, 2008, p. 59.

9 Ibidem, p. 52.

10 Ibidem, p. 111 
our confidence in the documentary character of photographs (a similar concept may be found in the deliberations of André Rouillé, whom I have mentioned above. The more artistic a photograph is: blurred, out of focus, inciting our imagination, the more it abandons the realism and truth). The author wonders whether the presence of abstraction and surrealism may cause the viewers to cease to assume the said authority.

A text in which the reader may find very controversial assumptions is the article by Roger Scruton. The main thesis proposed by the researcher is as follows: photography cannot represent anything, so the only kind of art that may fall under the definition of representational arts is painting. Scruton claims that we only deal with representation when a certain intentional relation occurs between a painting and its subject. A photograph and a photographed object do not stand in an intentional but casual relation which indicates that the photograph represents something that exists. Therefore, a photograph will not be a representation of something but merely a record of how an actual object looked at a particular time. With this statement Scruton moves on to discussing an interesting issue regarding the time of photography. Namely, he states that photography differs from the art of portraiture in the fact that it depicts its object at one particular moment, a time slice of reality, whereas a portraitist attempts to present his objects as continuous in time: "It is characteristic of photography that, being understood in terms of a causal relation to its subject, it is thought of as revealing something momentary about its subject - how the subject looked at a particular moment" ${ }^{11}$

As regards the temporariness of photography, similar conclusions were drawn by Roland Barthes. According to the French philosopher, photography is marked by death as a photograph presents a person, situation or an event of the past, and not of the present. A photographer immortalises in a photograph one particular moment, a facial expression or a gaze that in his opinion was worth immortalising, and he does so only once and will not be able to repeat it ever again. The only thing a photographer may do is mechanically reproduce a given photograph, for instance by making its prints. The same issue is addressed by the aforementioned François Soulages, who lists two main features of photography. The first is the infinity which consists in the fact that each photograph may be infinitely reproduced in the form of prints. This characteristic of photography results from the specificity of the tool we use in its realisation, namely the camera. The other property of photography is its irreversibility. Our intention is to capture a certain event, for instance, our child running in the rain across a meadow. Such exceptional circumstances: the place of an event, people participating in it, etc. - all of these aspects together happen only once, they will not return and we will

11 Ibidem, p. 148. 
not be able to take the same photograph for the second time. ${ }^{12}$ Soulages states that a once exposed film cannot be altered. We may only interfere with the negative. Barthesa further develops these observations and notes that when we take a photograph of a particular person by doing so we reduce their entire life to a concrete moment, the moment when the button on the camera is pressed. To a certain degree the photograph snatches a single point in the life of a person that it represents, which is not and cannot be the culmination of all other points. We may even state that photography creates an artificial image of a person it depicts.

Similarly to the authors I have mentioned earlier, Scruton also refers to the concept of transparency of photography. Transparency causes that a photograph may replace the object it represents. If a photograph is beautiful it means that the photographed object also has to be beautiful in reality. A matter related to a painterly work looks different. A painting may be beautiful even when it represents something which in reality may evoke repugnance and be disgusting (a corpse, wound, autopsy). The author's conclusion is as follows: only a representation of something may be recognised as a work of art. Photography does not represent but indicates something, hence it does not fall within the definition of a work of art, unless the process of its creation involved factors which belong to the process of photographing (for example, the photographer's intention or concept rejected by Kendall L. Walton), as a photographer does not influence the mechanical process of a photograph creation. This radical thesis is disputed by David Davies. In the article How Photographs "Signify": Cartier-Bresson's "Reply" to Scuton he refers to Rudolph Arnheim's analyses according to whom the method of presentation of a given object (such as the angle or direction of a take) depends on a photographer, thus a photograph itself may express the author's intention. Similar claims are voiced by Cartier-Bresson. He notices that a photographer is able to capture the relations and the meanings arising from the relations between particular events and figures depicted in photographs. Thus, Davies believes that photography should not be limited merely to its mechanicity. A photographer-artist>s idea and activity as well as the effect of their efforts, i.e. photographs, are to be recognised as works of art. Patrick Maynard expresses a similar opinion. In the article Scales of Space and Time in Photography: "Perception Points Two Ways" he describes all the factors a photographer needs to consider in order to ensure a good take. Thus, the quality of a photograph does not depend on the spatial sense of the photographer, his/her perceptiveness, the ability to capture the relations among several objects seen by the camera and the ability to compose a scene.

\footnotetext{
12 F. Soulages, Esthétique de la photographie: la perte et le reste, Paris: Nathan, 1998.
} 
It is impossible to summarise all the essays of the collection in such a short review. Nonetheless, the presented book is highly valuable and interesting. The reader will find there texts which present photography in different contexts. Each essay of the reviewed collection constitutes a thorough and detailed exposition filled with historical references. The articles have been written with the use of a fine language and the line of reasoning presented by each researcher is clear and comprehensive. What deserves praise is a broad historical background provided to introduce the discussed subject matter as well as the provision of numerous examples to illustrate a particular problem. It is worth noting that copies of the majority of the photographs discussed are also included in the presented collection. An insight into the illustrations facilitate the reader's understanding of an analysed issue. The work is preceded with a detailed introduction in which the editor precisely summarises particular articles and points to the relations existing between them. The said introduction constitutes a great hint for the reader whose interests lie with a particular topic related to photography. The book and its Polish translation contain an impressive bibliography and short notes of all the authors of the texts included in the collection. The book should be recommended to all of those who are interested in the issues of broadly defined modern aesthetics and the philosophy of visual arts. 